\title{
Evaluation of risk factors that contribute to falls among the elderly
}

Raquel Letícia Tavares Alves ${ }^{1}$

Carlos Fernando Moreira e Silva ${ }^{1}$ Luísa Negri Pimentel'

Isabela de Azevedo Costa'

Ana Cristina dos Santos Souza' ${ }^{1}$

Luma Aparecida Ferreira Coelho'

\section{Abstract}

Objective: to determine the incidence of falls among the elderly population of the city of Barbacena in the state of Minas Gerais, together with causal factors, circumstances and major consequences. Methods: a cross-sectional study was performed through questionnaires applied to 206 patients over the age of 60, from November 2014 to February 2015 in the city of Barbacena, in the state of Minas Gerais. Risk factors related to falls were analyzed, as well as the incidence of falls and the consequences for the lives of elderly persons. The existence of a relationship between the reporting of falls and possible risk factors was determined by the Chi-squared and Fischer's exact tests as indicated. Results: an incidence of falls of $36.41 \%$ was observed among the elderly, $45.95 \%$ of which occurred outside the home. A total of $85.71 \%$ of respondents had previously suffered strokes and $39.78 \%$ were taking medication. Among elderly persons who have fallen and suffered fractures (18.67\%), 50\% had suffered strokes, 50\% were suffering from chronic kidney disease, and $61.54 \%$ could not perform their activities of daily living after the fall. Conclusion: it was concluded that the incidence of falls among the elderly was $36.41 \%$, while the most correlated factors were drug use, stroke victims and people with chronic kidney disease. Among those who suffered fractures, $61.54 \%$ failed to perform activities of daily living. Preventing falls is a public health concern, and simple changes can reduce its prevalence.

Keywords: Aged. Drug Evaluation. Fractures, Bone.

Faculdade de Medicina de Barbacena. Minas Gerais, Brasil.

Correspondence

Raquel Letícia Tavares Alves

E-mail: raquelltalves@gmail.com 


\section{INTRODUCTION}

Aging is a natural, gradual and continuous process, which begins at birth and continues through every phase of life. The national policy for the elderly ${ }^{1}$ (Law $\mathrm{N}^{\circ} 8.842$ ) defines an elderly person as an individual aged 60 years or over. In Brazil, the number of people in this age group has risen sharply, characterizing the aging process that many other developing countries are also experiencing to a greater or lesser degree ${ }^{2}$. This new Brazil needs to accept the challenge of caring for health, not merely dealing with disease, and supporting families so that this becomes possible ${ }^{2,3}$. Among the problems of the elderly, falls are common events ${ }^{4}$, with multiple causes progressively increasing with age due to changes in gait, mechanisms of posture maintenance and muscle strength, which result in greater chances of stumbling and, consequently, falls ${ }^{5,6}$. Falls are a significant event among the elderly, as they can lead to incapacity, injury and death. Their social cost is immense and becomes greater when the elderly person has reduced autonomy and independence or needs to be institutionalized ${ }^{7}$.

Falls are the sixth most common cause of death among the elderly and account for $70 \%$ of accidental deaths among those aged 75 years or more $^{5}$. They therefore represent a major public health problem, as they can provoke fractures and trauma, as well as affecting the quality of life of the elderly due to psychosocial consequences, provoking feelings such as fear, frailty and lack of confidence, and often functioning as the beginning of the degeneration of the overall health profile of the elderly ${ }^{7-11}$.

Due to the importance of understanding the profile of falls among the elderly and the need to implement health policies that minimize the morbidity and mortality of elderly people who suffer from these events, the present study aimed to investigate the incidence of falls among the elderly of the city of Barbacena, Minas Gerais, correlating them with causal factors, the circumstances in which they occur and their main consequences.

\section{METHOD}

The present study took the form of a crosssectional observational analysis. The sample was selected by blocks based on the elderly residents in the area covered by the Estratégia da Saúde da Família (the Family Health Strategy) (ESF) of the Vilela Unidade Básica de Saúde (the Vilela Basic Health Unit) (UBS) in the city of Barbacena, Minas Gerais. This unit was chosen as it had a wider coverage of the elderly population (938) than the other UBS in the city. Elderly persons represented $14.43 \%$ of the overall population $(6,500)$ covered by the Vilela UBS.

The UBS cited was duly informed about the study and gave permission for the survey to be performed, which involved a total of 14 Community Health Agents. The health agents from the ESF teams agreed to carry out the work and were trained by researchers regarding the correct application of the questionnaires during home visits, which occurred from November 2014 to February 2015.

They were advised that each item of the questionnaire should be put verbally by the community agents to the elderly persons or caregivers in a clear and easy to understand manner, using lay vocabulary. The answers were scored by the community health agents themselves in an assertive or dissertative manner, depending on the item in question.

Individuals older than 60 years were included in the study and, when there was some difficulty with communication and/or the memory of the elderly person, the companions or caregivers who were present at the moment of the survey were interviewed.

Those individuals under 60 years of age and those with memory and/or communication difficulties who were not accompanied by persons who could respond to the questionnaire were excluded from the study.

The questionnaire was developed by the researchers of this study and consisted of 14 questions adapted from previously validated questionnaires ${ }^{12,13}$ which included age, gender, occurrence of falls in the previous year, location of fall, occurrence of 
fractures, number of fractures and their anatomical location, requirement of hospitalization due to the fall, the presence of difficulty or the impediment of performing daily activities after a fall, the use of medications, environmental risk factors and the presence of comorbidities associated with this phase of life. These questions were formulated to avoid technical vocabulary, using lay terms, to facilitate the understanding of the research participants. A cerebrovascular accident was referred to as a stroke, for example, to facilitate the understanding of the health agents who applied the questionnaire and the elderly persons or caregivers who responded. The questionnaires were applied following the signing of a Free and Informed Consent Form (FICF).

The sample size calculated for this study was 196 elderly persons, based on a population of 126,284 inhabitants counted in the Demographic Census of $2010^{14}$, and a maximum percentage of elderly persons of $15 \%$ of the population, with a confidence interval of $95 \%$ and a margin of error of $5 \%$.

Frequency distributions were constructed and the mean, standard deviation and percentage were calculated for each variable. The existence of a relationship between the reports of falls and possible risk factors (comorbidities, drug use and environmental factors) were assessed using the Chi-squared and Fischer's exact tests as indicated. Differences with a $p$-value less than or equal to 0.05 were considered significant.

The study was approved by the Ethics Research Committee of the Fundação Hospitalar do Estado de Minas Gerais (FHEMIG) (the Hospital Foundation of the State of Minas Gerais) under protocol number CAAE 30314514.8.0000.5156, on August 21, 2014.

\section{RESULTS}

After applying the questionnaires during the data collection period, information regarding 206 patients was obtained. Table 1 shows their sociodemographic characteristics. Of the interviews performed, $85.44 \%$ were answered by the elderly persons themselves while $14.56 \%$ were answered by their companions. In terms of the age of the patients enrolled in the study, it was observed that $45.66 \%$ of the patients were aged between 60 and 69 years old, $54.37 \%$ were between 70 and 98 years old, and the mean age of the elderly persons was $71.4( \pm 7.5)$ years. With regard to gender and occupation, there was a predominance of women and retired elderly persons.

Table 1: Sociodemographic characteristics of elderly participants of study. Barbacena, Minas Gerais, 2015.

\begin{tabular}{lllll}
\hline Characteristics Compared & $\begin{array}{l}\text { No falls in } \\
\text { previous year } \\
\mathrm{n}(\%)\end{array}$ & $\begin{array}{l}\text { Fall in previous } \\
\text { year } \\
\mathrm{n}(\%)\end{array}$ & X2/F & $p$ \\
\hline $\begin{array}{l}\text { Questionnaire answered by } \\
\text { Elderly Person }\end{array}$ & $116(65.91)$ & $60(34.09)$ & 2.80 & $0.04^{*}$ \\
Companion & $15(50.00)$ & $15(50.00)$ & & \\
\hline Age Group (Years) & & & 1.51 & $0.220^{*}$ \\
$60-69$ & $64(68.09)$ & $30(31.91)$ & & \\
$70-98$ & $67(59.82)$ & $45(40.18)$ & & $0.078^{*}$ \\
Gender & & & 3.12 & \\
Female & $84(59.57)$ & $57(40.43)$ & & $0.713^{* *}$ \\
Male & $47(72.31)$ & $18(27.69)$ & & \\
\hline Occupation & & & & \\
Retired & $125(63.13)$ & $73(36.87)$ & & \\
Working & $6(75.00)$ & $2(25,00)$ & & \\
\hline
\end{tabular}

$* p$ value from Chi-squared test; ${ }^{* *} p$ value from Fisher's Exact Test. 
Regarding the possible risk factors for the occurrence of falls, we evaluated the presence of comorbidities, the use of medications and environmental factors, such as the presence of steps and rugs, as well as whether the elderly person resided alone or not, as shown in Table 2.

Regarding the occurrence of falls in the previous year, the data showed that $36.41 \%$ of the elderly persons had suffered a fall. Of the elderly who had fallen, most had suffered only one fall. The questionnaire applied also included where the fall occurred, with $45.95 \%$ of the elderly falling outside the home and $13.51 \%$ suffering falls both inside and outside the home. Among the elderly who fell at home, the places with the highest incidence of falls were: $21.95 \%$ in the bathroom, $19.51 \%$ in the external area of the house and $17.07 \%$ in the bedroom.

Regarding the consequences of falls, the first factor analyzed was the occurrence of fractures,

Table 2- Clinical, drug and environmental risk factor characteristics for falls among elderly persons. Barbacena, Minas Gerais, 2015.

\begin{tabular}{|c|c|c|c|c|}
\hline Características Comparadas & $\begin{array}{l}\text { No fall in previous year } \\
\mathrm{n}(\%)\end{array}$ & $\begin{array}{l}\text { Fall in previous year } \\
\mathrm{n}(\%)\end{array}$ & $\mathrm{X} 2 / \mathrm{F}$ & $p$ \\
\hline \multicolumn{5}{|l|}{ Comorbidities } \\
\hline Diabetes Mellitus & $24(53.33)$ & $21(43.67)$ & 2.53 & $0.112^{*}$ \\
\hline Cerebrovascular accident & $1(14.29)$ & $6(85.71)$ & & $0.010^{* *}$ \\
\hline Parkinson's & $0(00.00)$ & $1(100.0)$ & & $0.366^{* *}$ \\
\hline Forgetfulness & $16(45.71)$ & $19(54.29)$ & 5.70 & $0.017 *$ \\
\hline Hypertension & $91(59.48)$ & $62(40.52)$ & 4.35 & $0.037 *$ \\
\hline Heart Attack & $5(45.45)$ & $6(54.55)$ & & $0.199 * *$ \\
\hline Kidney disease & $10(55.56)$ & $8(44.44)$ & 0.55 & $0.458^{*}$ \\
\hline Osteoporosis & $24(50.00)$ & $24(50.00)$ & 4.99 & $0.025^{*}$ \\
\hline Arthrosis & $30(51.72)$ & $28(48.28)$ & 4.91 & $0.027 *$ \\
\hline Arthritis & $15(48.39)$ & $16(51.61)$ & 3.64 & $0.056^{*}$ \\
\hline Difficulty of movement & $12(33.33)$ & $24(63.67)$ & 17.25 & $0.000^{*}$ \\
\hline Depression & $20(44.44)$ & $25(55.56)$ & 9.12 & $0.003^{*}$ \\
\hline Visual impairment & $40(55.56)$ & $32(44.44)$ & 3.09 & $0.079 *$ \\
\hline Use of medicines & & & & $0.014^{* *}$ \\
\hline No & $16(84.21)$ & $3(15.79)$ & & \\
\hline Did not answer & $6(100.00)$ & $0(0.00)$ & & \\
\hline Yes & $109(60.22)$ & $72(39.78)$ & & \\
\hline Psychotropic drugs & $34(52.31)$ & $31(47.69)$ & 7.28 & $0.026^{*}$ \\
\hline Hypoglycemic agents & $23(56.10)$ & $18(43.90)$ & 1.24 & $0.265^{*}$ \\
\hline Antihypertensives & $91(59.87)$ & $61(40.13)$ & 3.47 & $0.062 *$ \\
\hline Other Medications & $55(57.29)$ & $41(42.71)$ & $3 ., 08$ & $0.079 *$ \\
\hline \multicolumn{5}{|l|}{ Environmental conditions } \\
\hline Live alone & $26(66.67)$ & $13(33.33)$ & 0.20 & $0.658^{*}$ \\
\hline Stairs & & & 2.10 & $0.552^{*}$ \\
\hline None & $46(67.65)$ & $22(32.35)$ & & \\
\hline Up to 5 & $33(67.35)$ & $16(32.65)$ & & \\
\hline 6-10 & $28(56.00)$ & $22(44.00)$ & & \\
\hline More than 10 steps & $24(61.54)$ & $15(38.46)$ & & \\
\hline Has rugs at home & $46(60.53)$ & $30(39.47)$ & 0.49 & $0.484^{*}$ \\
\hline
\end{tabular}

${ }^{*} p$ value from Chi-squared test; ${ }^{* *} p$ value from Fisher's Exact Test. 
which affected $8.67 \%$ of the elderly. Regarding age, the study showed that the percentage of fractures in individuals aged 60-69 years was $23.33 \%$, while among those aged $70-98$ years it was $15.56 \%$. As for gender, there was a higher incidence of falls among females, as shown in Table 3.

The clinical and environmental characteristics of the elderly patients who suffered fractures were also evaluated (Table 4). It was verified that those with frequent forgetfulness, followed by patients with Diabetes Mellitus, visual disabilities and hypertension had a higher occurrence of fractures. It was also verified that $57.14 \%$ of the fractures occurred in the upper limbs, $28.57 \%$ in the lower limbs and the remainder in the pelvis or head (TBI). When asked about the environment where they suffered the fracture, the study showed that $20.00 \%$ of fractures occurred after falls suffered in the home, with the bedroom being the room where fractures occurred most frequently.

Table 3: Sociodemographic characteristics of elderly patients that suffered a fracture following a fall. Barbacena, Minas Gerais, 2015.

\begin{tabular}{lllll}
\hline Characteristics Compared & $\begin{array}{l}\text { No fracture } \\
\mathrm{n}(\%)\end{array}$ & $\begin{array}{l}\text { Fracture } \\
\mathrm{n}(\%)\end{array}$ & $\mathrm{X} 2 / \mathrm{F}$ & $p$ \\
\hline $\begin{array}{l}\text { Questionnaire answered by } \\
\text { Elderly Person }\end{array}$ & $51(85.00)$ & $9(15.00)$ & 2.66 & $0.103^{*}$ \\
Companion & $10(66.67)$ & $5(33.33)$ & & \\
\hline Age Group (Years) & & & 0.72 & $0.397^{*}$ \\
$60-69$ & $23(76.67)$ & $7(23.33)$ & & \\
$70-98$ & $38(84.44)$ & $7(15.54)$ & & \\
\hline Gender & & & & 0.06 \\
Female & $46(80.70)$ & $11(19.30)$ & & \\
Male & $15(83.33)$ & $3(16.67)$ & & \\
\hline Occupation & & & & \\
Retired & $60(82.19)$ & $13(17.81)$ & & \\
Working & $1(50.00)$ & $1(50.00)$ & & \\
\hline
\end{tabular}

$* p$ value from Chi-squared test.

Another impact of falls evaluated in the study was the occurrence of hospitalization after the same. It was verified that $31.08 \%$ of patients who had fallen in the previous year were hospitalized as a result of the fall, with the majority being retired, male (44.44\%) and aged between 60 and 69 years (40\%). Regarding the clinical, drug and environmental factors investigated, statistical significance was only found in patients with renal disease, who were associated with a $62.50 \%$ incidence of hospitalizations $(p=0.042)$.

Table 4 - Clinical, drug and environmental risk factors for fractures among elderly persons after a fall. Barbacena, Minas Gerais, 2015.

\begin{tabular}{lllll}
\hline Characteristics Compared & $\begin{array}{l}\text { No fracture } \\
\mathrm{n}(\%)\end{array}$ & $\begin{array}{l}\text { Facture } \\
\mathrm{n}(\%)\end{array}$ & $\mathrm{X} 2 / \mathrm{F}$ & $p$ \\
\hline Comorbidities & & & & \\
Diabetes Mellitus & $24(53.33)$ & $21(43.67)$ & 2.53 & $0.112^{*}$ \\
Stroke & $3(50)$ & $3(50)$ & 4.22 & $0.040^{*}$ \\
Parkinson's & $1(100)$ & $0(0)$ & & $1.000^{*}$ \\
& & & to be continued
\end{tabular}


continued from table 4

\begin{tabular}{|c|c|c|c|c|}
\hline Forgetfulness & $10(52.63)$ & $9(47.37)$ & 13.81 & $0.000 *$ \\
\hline Hypertension & $53(85.48)$ & $9(14.52)$ & 4.06 & $0.044 *$ \\
\hline Heart Attack & $5(83.33)$ & $1(16.67)$ & & $1.000^{*}$ \\
\hline Kidney disease & $4(50)$ & $4(50)$ & 5.79 & $0.016^{*}$ \\
\hline Osteoporosis & $19(79.17)$ & $5(20.83)$ & 0.11 & $0.741^{*}$ \\
\hline Arthrosis & $24(85.71)$ & $4(14.29)$ & 0.56 & $0.452 *$ \\
\hline Arthritis & $12(75)$ & $4(25)$ & 0.54 & $0.464 *$ \\
\hline Difficulty of movement & $19(79.17)$ & $5(20.83)$ & 0.11 & $0.741^{*}$ \\
\hline Depression & $19(76)$ & $6(24)$ & 0.70 & $0.402 *$ \\
\hline Visual impairment & $24(75)$ & $8(25)$ & 1.47 & $0.225^{*}$ \\
\hline Use of medicines & & & 0.44 & $0.506^{*}$ \\
\hline No & $2(66.67)$ & $1(33.33)$ & & \\
\hline Yes & $59(81.94)$ & $13(18.06)$ & & \\
\hline Psychotropic drugs & $26(83.87)$ & $5(16.13)$ & 0.22 & $0.636^{*}$ \\
\hline Hypoglycemic agents & $15(83.33)$ & $3(16.67)$ & 0.06 & $0.803^{*}$ \\
\hline Antihypertensives & $53(86.89)$ & 8 (13.11) & 6.63 & $0.010^{*}$ \\
\hline Other Medications & $30(73.17)$ & $11(26.83)$ & 3.97 & $0.046^{*}$ \\
\hline \multicolumn{5}{|l|}{ Environmental conditions } \\
\hline Live alone & $10(76.92)$ & $3(23.08)$ & 0.20 & $0.654^{*}$ \\
\hline Stairs & & & 2.09 & $0.554^{*}$ \\
\hline None & $18(81.82)$ & $4(18.18)$ & & \\
\hline Up to 5 & $12(75)$ & $4(25)$ & & \\
\hline $6-10$ & $17(77.27)$ & $5(22.73)$ & & \\
\hline More than 10 stairs & $14(93.33)$ & $1(6.67)$ & & \\
\hline Has rugs at home & $26(86.67)$ & $4(13.33)$ & 0.94 & $0.333^{*}$ \\
\hline
\end{tabular}

$* p$ value from Chi-squared test.

Table 5-General characteristics of patients in relation to daily activities following a fall. Barbacena, Minas Gerais, 2015.

\begin{tabular}{llllll}
\hline Characteristics Compared & $\begin{array}{l}\text { Following fall Stopped } \\
\mathrm{n}(\%)\end{array}$ & $\begin{array}{l}\text { Continued } \\
\mathrm{n}(\%)\end{array}$ & $\begin{array}{l}\text { Had difficulty } \\
\mathrm{n}(\%)\end{array}$ & $\mathrm{X} 2 / \mathrm{F}$ & $p$ \\
\hline $\begin{array}{l}\text { Questionnaire answered by } \\
\text { Companion }\end{array}$ & $6(40)$ & $3(20)$ & $6(40)$ & 10.19 & $0.006^{*}$ \\
Elderly Person & $7(11.67)$ & $37(61.67)$ & $16(26.67)$ & & \\
\hline Stroke & & & & & $0.003^{* *}$ \\
No & $12(17.39)$ & $40(57.97)$ & $17(24.64)$ & & \\
Yes & $1(16.67)$ & $0(0)$ & $5(83.33)$ & & $0.022^{*}$ \\
\hline Arthrosis & & & & 7.60 & \\
No & $12(25.53)$ & $25(53.19)$ & $10(21.28)$ & & $0.004^{*}$ \\
Yes & $1(3.57)$ & $15(53.57)$ & $12(42.86)$ & & \\
\hline Difficulty Moving & & & & 11.29 & \\
No & $9(17.65)$ & $33(64.71)$ & $9(17.65)$ & & \\
Yes & $4(16.67)$ & $7(29.17)$ & $13(54.17)$ & & \\
\hline
\end{tabular}

${ }^{*} p$ value from Chi-squared test; ${ }^{* *}$ p value from Fisher's Exact Test. 
Regarding the impact of falls on the elderly in terms of the performance of their daily activities, $53.33 \%$ continued to perform their activities as they did prior to the fall, $29.33 \%$ began to present difficulties and $17.33 \%$ patients could no longer perform these activities. It was also verified that patients who reported having suffered a stroke, had arthrosis or had difficulty moving around, experienced problems performing daily activities after a fall more frequently than patients who did not suffer from these diseases, as shown in Table 5.

\section{DISCUSSION}

The occurrences of falls observed in the present study followed the patterns found in other studies performed in western countries. The incidence of falls of $36.41 \%$ was compatible with data found in Brazilian and non-Brazilian literature ${ }^{8,15,16}$. In a cohort study performed in the city of São Paulo by Perracini and Ramos ${ }^{8}$, around $31.00 \%$ of elderly persons said they had fallen in the year before the survey. Similar values were found in other Brazilian and non-Brazilian studies, with the $\mathrm{WHO}$ also adopting a value of $30.00 \%{ }^{17}$ as an estimate of falls in people over 65 years of age. It is worth noting that even in non-Brazilian studies, which generally adopt different ages as inclusion criterion for the elderly group, the results were equivalent.

The findings of the present study regarding the subdivision between female $(68.45 \%)$ and male $(31.55 \%)$, the mean age of the elderly interviewed (71.4 years) and the fact that the highest incidence of falls occurred among women (76.00\%) were also verified in other works. According to a study carried out in the city of Ribeirão Preto by Fabricio et $\mathrm{al}^{4}{ }^{4}, 66.00 \%$ of falls victims were female, while the average age of the elderly persons surveyed was 76 years and there was an incidence of falls among women of $66.00 \%$. In several other studies, the variable of being a woman increased the occurrence of falls independently and significantly ${ }^{4,8,15,18,19}$. The possible causes to explain this phenomenon may be related to the fact that the absolute number of elderly persons who fell was higher among elderly women, the greater physical frailty of women, the lower amount of lean mass and muscular strength compared to men of the same age ${ }^{8}$, the greater loss of bone mass due to the reduction of estrogen ${ }^{20}$, the greater occurrence of chronic diseases, as well as the greater involvement of women in domestic activities and their longer life expectancy. Contrary to expectations, in the present study there was no significant difference in gender in relation to fractures. This lack of significance may be related to the sample size, as the factors that contribute to fractures in women are relevant ${ }^{4,8,15,18,19,21}$.

In terms of the impact of the neurological diseases evaluated on the incidence of falls, no statistically significant association was found between the incidence of Parkinson's and the occurrence of falls, a finding contrary to other studies $^{22}$. The absence of this association is probably due to the sample, which included only one patient with the disease.

Studies indicate that the incidence of strokes increases with age, doubling with each decade of life from 55 years of age onwards. Among the complications that result from strokes are postural imbalance and depression, influencing elements of postural control and resulting in flaws in the process of sensory construction and the generation of motor responses ${ }^{23}$. This explains the finding of a positive association with a previous history of strokes, referred to as such rather than cerebrovascular accidents in the applicable question, with $85.71 \%$ of patients having suffered falls in the last year, a significantly higher percentage than that found among the general population. The percentage found was similar to that observed in an Austrian study conducted by Homann et al..$^{22}$ in which a prevalence of falls of $89 \%$ in patients with a previous history of strokes was recorded.

An association between frequent forgetfulness and the occurrence of falls was also found. Dementia, of which forgetfulness is an important component, is associated with a rate of falls of $60 \%{ }^{22,24}$ which explains the association identified. Depression and dementia are two of the most recurrent diseases of geriatrics, as they frequently combine, with one even simulating the other, which can cause difficulties with diagnosis ${ }^{24}$. A significant relationship was found between the occurrence of falls and patients who reported having depression. This association can be 
explained by the incapacitation and subsequent functional decline observed in depressed elderly persons ${ }^{25}$. It is worth mentioning that the association between falls and forgetfulness can also be explained by the frequent coexistence between depression and dementia. It is important to note that the rate of fractures was also higher in patients who self-reported frequent forgetfulness and depression. Falls were also more frequent in patients with osteoporosis, osteoarthritis and difficulty in movement. Falls are more frequent among those diagnosed with osteoporosis, since the presence of this pathology is associated with the female gender and advanced age ${ }^{20}$. Contrary to expectations, the incidence of fractures in patients with osteoporosis was not higher. This is likely due to the sample size of the present study. As a fracture is a clinical consequence of osteoporosis, the occurrence of a fall would further favor the incidence of fractures in this group of patients, a finding presented in several studies ${ }^{26}$.

No significant association was found between the previous occurrence of acute myocardial infarction (AMI), diabetes mellitus (DM), renal disease and visual impairment and the incidence of falls. Despite this, literature reports a higher incidence of falls in individuals with renal disease, especially those treated with hemodialysis ${ }^{27}$.

When the occurrence of fractures was compared with the location of the falls, it was observed that most of the elderly persons who fell suffered fractures in the home $(20.00 \%)$ and both indoors and outdoors $(50.00 \%)^{21}$. Regarding the anatomical location, the majority of fractures were found in the upper limbs (57.14\%), followed by the lower limbs $(28.57 \%)$. This finding differs from that of a study by Hamra et al. ${ }^{21}$, in which there was a greater incidence of femoral fractures. Such a finding can be explained by the fact that the upper limbs, especially the wrist, provide support at the time of the fall and are more subject to the impact of the fall.

When the medication used by the elderly were analyzed, a significant difference was observed with the use of antihypertensive drugs. Such drugs can cause side effects such as postural hypotension, dizziness, the need to urinate more frequently, among other effects, which can lead to falls and consequently fractures ${ }^{21,28-30}$.

Another significant result was obtained in relation to the performance of daily activities after the fracture, which showed that the performance of such activities declined among the majority of individuals who suffered a fracture $(61.54 \%)$. This finding contrasts with the study by Antes et al. ${ }^{19}$, which showed that among the elderly persons investigated, most maintained their performance of daily activities post-fall and post-fracture. It was observed that diseases that cause movement limitation and result in greater dependence on caregivers were more relevant in the study undertaken. After a fall, the highest percentage of elderly people who did not perform their daily activities were found in patients who had suffered a stroke and those with some previous movement difficulties ${ }^{22}$.

Regarding the sociodemographic characteristics of patients who were hospitalized after falls, it was observed that the incidence of hospitalization was higher in the group in which the questionnaire was answered by a companion. According to studies on the functional evaluation of elderly victims of falls and hospitalization, the observed decline in functional independence during the follow-up period when the elderly person was at home could be explained by family protectionism. In such situations, relatives perform such activities for the elderly person or request assistance from caregivers, believing the elderly person to be incapable of carrying out such activities themselves, or as a way of expressing enthusiasm and affection for the convalescent individual. It is believed that these factors can increase the probability of falls as they reduce the autonomy of the elderly, favoring the increase of hospitalization after the fall verified in the study ${ }^{31}$.

In terms of the clinical and medication related characteristics and the environmental risk factors related to the hospitalization of elderly patients who suffered falls, studies indicate that the main risk factors for falls in this population are related to functional limitation ${ }^{31,32}$, a previous history of falls, increased age ${ }^{33}$, muscle weakness ${ }^{34}$, use 
of psychotropic medications ${ }^{29}$, environmental risks, the female gender ${ }^{4,8,15,18,19,21}$, as well as visual impairment. Although the present study identified a greater occurrence of hospitalization due to falls in patients with renal disease, no studies were found in literature to verify this association. This fact may be justified, however, by chronic renal patients exhibiting systemic disorder characterized by anomalies of calcium, phosphorus, PTH and vitamin D in their metabolisms, which may cause skeletal changes ${ }^{35}$.

\section{REFERENCES}

1. BRASIL. Ministério do Desenvolvimento Social e Combate a Fome. Política Nacional do Idoso. Lei $\mathrm{n}^{\circ}$ 8.842, de janeiro de 1994. Dispõe sobre a política nacional do idoso, cria o Conselho Nacional do Idoso e dá outras providências. Sociedade Brasileira de Geriatria e Gerontologia; 2014. Disponível em: http:// sbgg.org.br/wp-content/uploads/2014/10/politicanacional-do-idoso.pdf.

2. Kuchemann BA. Envelhecimento populacional, cuidado e cidadania: velhos dilemas e novos desafios. Soc Estado [Internet].2012 [acesso em 16 nov 2016];27(1):165-80. Disponível em: http://www. scielo.br/scielo.php?script=sci_arttext\&pid=S010269922012000100010\&lng=pt\&nrm=iso\&tlng=en

3. Brito MCC, Freitas CASL, De Mesquita KO, Lima GK. Envelhecimento populacional e os desafios para a saúde pública: análise da produção científica. Rev Kairós [Internet]. 2013 [acesso em 16 nov 2016];16(3):161-78. Disponível em: http:// revistas.pucsp.br/index.php/kairos/article/ viewFile/18552/13738

4. Fabrício SCC, Rodrigues RAP, Costa JML. Causas e conseqüências de quedas de idosos atendidos em hospital público. Rev Saúde Pública [Internet]. 2004 [acesso em 16 nov 2016];38(1):93-9. Disponível em: http://www.scielo.br/pdf/rsp/v38n1/18457.pdf

5. Guimarães JMN, Farinatti PDTV. Análise descritiva de variáveis teoricamente associadas ao risco de quedas em mulheres idosas. Rev Bras Med Esporte [Internet]. 2005 [acesso em 16 nov 2016];11:299-305. Disponível em: http://migre.me/vvOUK

6. Toledo DR, Barela JA. Diferenças sensoriais e motoras entre jovens e idosos: contribuição somatossensorial no controle postural. Rev Bras Fisioter [Internet]. 2010 [acesso em 16 nov 2016];14(3):267-75. Disponível em: http://www.scielo.br/pdf/rbfis/v14n3/04.pdf

\section{CONCLUSION}

The incidence of falls among the elderly in the present study was $36.41 \%$, and the most correlated factors were medication use and being the victim of a stroke or a chronic kidney disease patient. Of those who suffered a fracture, $61.54 \%$ no longer performed their daily activities. The prevention of falls is therefore a public health concern and relatively simple changes can reduce the risk of their occurrence.
7. Pereira SEM, Buksman S, Perracini M, Py L, Barreto KML, Leite VMM. Quedas em idosos: Projeto Diretrizes [Internet]. Rio de Janeiro: Sociedade Brasileira de Geriatria e Gerontologia; 2001 [acesso em 16 nov 2016]. Disponível em : http://www. portalmedico.org.br/diretrizes/quedas_idosos.pdf

8. Perracini MR, Ramos LR. Fatores associados a quedas em uma coorte de idosos residentes na comunidade. Rev Saúde Pública [Internet]. 2002 [acesso em 16 nov 2016];36(6):709-16. Disponível em: http://www. scielo.br/scielo.php?script=sci_arttext\&pid=S0034$89102002000700008 \& \operatorname{lng}=$ pt\&nrm $=$ iso $\&$ tlng $=$ pt

9. Ribeiro AP, Souza ER, Atie S, Souza AC, Schilithz AO. A influência das quedas na qualidade de vida de idosos. Ciênc Saúde Coletiva [Internet]. 2008 [acesso em 16 nov 2016];13(4):1265-73. Disponível em: http://www.scielo.br/scielo.php?script=sci_ arttext\&pid=S1413-81232008000400023\&lng=pt\&nr $\mathrm{m}=$ iso\&tlng $=\mathrm{pt}$

10. World Health Organization. WHO Global report on falls prevention in older age [Internet]. Geneva: WHO; 2007 [acesso em 16 nov 2016]. Disponível em: http://www.who.int/ageing/publications/Falls_ prevention7March.pdf

11. Secoli SR. Polifarmácia: interações e reações adversas no uso de medicamentos por idosos. Rev Bras Enferm [Internet]. 2010 [acesso em 16 nov 2016];63(1):136-40. Disponível em: http://www.scielo. br/pdf/reben/v63n1/v63n1a23.pdf

12. Valente SFP. Validação de um Questionário de Saúde e Identificação de Fatores de Risco de Quedas para a população idosa portuguesa [tese]. Lisboa: Universidade Técnica de Lisboa; Faculdade de Motricidade Humana; 2012 [acesso em 16 nov 2016]. Disponível em: https://www.repository. utl.pt/bitstream/10400.5/.../MSC\%20versão\%20 definitiva.pdf 
13. Tiedemann A, Lord SR, Sherrington C. The development and validation of a Brief PerformanceBased Fall Risk Assessment Tool for Use in Primary Care. J Gerontol Ser A Biol Sci Med Sci [Internet]. 2010 [acesso em 16 nov 2016],65A(8):896903. Disponível em: http://biomedgerontology. oxfordjournals.org/content/65A/8/896.long

14. Instituto Brasileiro de Geografia e Estatística. Censo Demográfico 2010 [Internet]. Rio de Janeiro: IBGE; 2010 [acesso em 16 nov 2016]. Disponível em: http:// www.ibge.gov.br/home/estatistica/populacao/ censo2010/

15. Cruz DT, Ribeiro LC, Vieira MT, Teixeira MTB, Bastos RR, Leite ICG. Prevalência de quedas e fatores associados em idosos. Rev Saúde Pública [Internet]. 2012 [acesso em 16 nov 2016];46(1):13846. Disponível em: http://www.scielo.br/pdf/rsp/ v46n1/3070.pdf

16. Soares WJS, Moraes SA, Ferriolli E, Perracini MR. Fatores associados a quedas e quedas recorrentes em idosos: estudo de base populacional. Rev. Bras. Geriatr. Gerontol [Internet] 2014 [acesso em 16 nov 2016];17(1): 49-60. Disponível em : http://www.scielo. br/pdf/rbgg/v17n1/1809-9823-rbgg-17-01-00049.pdf

17. Skelton D, Todd C. What are the main risk factors for falls amongst older people and what are the most effective interventions to prevent these falls? How should interventions to prevent falls be implemented? [Internet]. Copenhagen: WHO Europe; 2004 [acesso em 16 nov 2016. Disponível em : http://www.euro.who.int/__data/assets/pdf_ file/0018/74700/E82552.pdf

18. Gama ZAS, Gómez-Conesa A. Factores de riesgo de caídas enancianos: revisión sistemática. Rev Saúde Pública [Internet]. 2008 [acesso em 16 nov 2016];42:946-56. Disponível em: http://www.scielo. br/pdf/rsp/v42n5/6793.pdf

19. Antes DL, Orsi E, Benedetti TR. Circunstâncias e consequências das quedas em idosos de Florianópolis. EpiFloripa Idoso 2009. Rev Bras Epidemiol [Internet]. 2013 [acesso em 16 nov 2016];16(2):469-81. Disponível em : http://www.scielo.br/pdf/rbepid/ v16n2/1415-790X-rbepid-16-02-00469.pdf

20. Da Cruz DT, Ribeiro LC, Vieira MT, Teixeira MTB, Bastos RR, Leite ICG. Prevalência de quedas e fatores associados em idosos. Rev. Saúde Pública [Internet]. 2012 [acesso em 16 nov 2016];46(1):138-46. Disponível em: http://dx.doi.org/10.1590/S003489102011005000087

21. Hamra A, Ribeiro MB, Miguel OF. Correlação entre fratura por queda em idosos e uso prévio de medicamentos. Acta Ortop Bras [Internet]. 2007 [acesso em 16 nov 2016];15(3):143-45. Disponível em: http://www.scielo.br/pdf/csp/v28n12/02.pdf
22. Homann B, Plaschg A, Grundner M Haubenhofer A Griedl T, Ivanic G, et al. The impact of neurological disorders on the risk for falls in the community dwelling elderly: a case-controlled study. BMJ [Internet]. 2013 [acesso em 16 nov 2016];3(11):19. Disponível em: http://bmjopen.bmj.com/ content/3/11/e003367.full

23. Tanaka AFD, Scheicher ME. Relação entre depressão e desequilíbrio postural em idosos que sofreram acidente vascular encefálico. Fisioter Mov [Internet]. 2013 [acesso em 16 nov 2016];26(2):315-20. Disponível em: http://dx.doi.org/10.1590/S010351502013000200008

24. Ramos TS. Depressão e demência no idoso: diagnóstico diferencial e correlações [tese]. Porto: Universidade do Porto, Instituto de Ciências Biomédicas Abel Salazar; 2014 [acesso em 16 nov 2016]. Disponível em: https://sigarra.up.pt/ffup/pt/ pub_geral.show_file?pi_gdoc_id=612566

25. Valcarenghi RV, Santos SSC, Barlem ELD, Pelzer MT, Gomes GC, Lange C. Alterações na funcionalidade/cognição e depressão em idosos institucionalizados que sofreram quedas. Acta Paul Enferm [Internet]. 2011 [acesso em 16 nov 2016];24(6):828-33. Disponível em: http://www.scielo. br/pdf/ape/v24n6/a17v24n6.pdf

26. Riera R, Trevisani VF, Ribeiro JPN. Osteoporose: a importância da prevenção de quedas. Rev Bras Reumatol [Internet]. 2003 [acesso em 16 nov 2016];43(6):364-68. Disponível em : http://dx.doi. org/10.1590/S0482-50042003000600008

27. Abdel-Rahman EM, Turgut F, Turkmen K. Falls in elderly hemodialysis patients. QJM [Internet]. 2011 [acesso em 16 nov 2016];104(10):829-38. Disponível em: http://qimed.oxfordjournals.org/ content/104/10/829

28. Woolcott JC, Richardson JK, Wiens MO, Patel B, Marin J, Khan KM, et al Meta-analysis of the impact of 9 medication classes onfalls in elderly persons. Arch Intern Med [Internet]. 2009 [acesso em 16 nov 2016];169(21):1952-60. Disponível em: http:// jamanetwork.com/journals/jamainternalmedicine/ fullarticle/485251

29. Bloch F, Thibaud M, Dugué B, Brèque C, Rigaud AS, Kemoun G. Psychotropic drugs and falls in the elderly people: updated literature review and metaanalysis. J Aging Health [Internet] 2011 [acesso em 16 nov 2016], 23(2):329-46. Disponível em : https://www.ncbi.nlm.nih.gov/pubmedhealth/ PMH0032439/ 
30. Thibaud M, Bloch F, Facon TC, Brèque C, Rigaud AS, Dugué B, et al. Impact of physical activity and sedentary behaviour on fall risks in older people: a systematic review and meta-analysis of observational studies. Eur Rev Aging Phys Act [Internet]. 2012 [acesso em 16 nov 2016],9(1):5-15. Disponível em: http://link.springer.com/article/10.1007/s11556-0110081-1

31. Monteiro CR, Faro ACM. Avaliação funcional de idoso vítima de fraturas na hospitalização e no domicílio. Rev Esc Enferm USP [Internet]. 2010 [acesso em 16 nov 2016];44(3):719-24. Disponível em: http://www.scielo.br/pdf/reeusp/v44n3/24.pdf

32. Pereira GN, Morsch P, Lopes DGC, Trevisan MD, Ribeiro A, Navarro JHN, et al . Fatores socioambientais associados à ocorrência de quedas em idosos. Ciênc Saúde Coletiva [Internet]. 2013 [acesso em 16 nov 2016];18(12):3507-14. Disponível em: http://dx.doi.org/10.1590/S1413-81232013001200007
33. Marques RTS, Moraes AB, Peripolli A, Santos VAVSF. Perfil epidemiológico de idosos que foram a óbito por queda no Rio Grande do Sul. Rev Bras Geriatr Gerontol [Internet]. 2015 [acesso em 16 nov 2016];18(1):59-69. Disponível em: http://dx.doi. org/10.1590/1809-9823.2015.14017

34. Aveiro MC, Driusso P, Barham EJ, Pavarini SCI, Oishi J. Mobilidade e risco de quedas de população idosa da comunidade de São Carlos. Ciênc Saúde Coletiva [Internet]. 2012 [acesso em 16 nov 2016];17(9):2481-88. Disponível em: http://dx.doi. org/10.1590/S1413-81232012000900028

35. Górriz JL, Molina P, Bover J, Barril G, Martín-de Francisco AL, Caravaca F, et al . Características del metabolismo óseo y mineral en pacientes conenfermedad renal crónica em estadios 3-5 no endiálisis: resultados del estudio OSERCE. Nefrología [Internet]. 2013 [acesso em 16 nov /2016];33(1):46-60. Disponível em: http://dx.doi. org/10.3265/Nefrologia.pre2012.Nov.11703 